\title{
政

\section{Simultaneous treatment with Carbimazole and Granulocyte-colony stimulating factor in a patient with thyrotoxicosis and Carbimazole induced neutropenia}

\author{
Indrajit Talapatra*, Vengal Reddy Nagareddy, \\ Manju Bhavnani, David James Tymms \\ Royal Albert Edward Infirmary, \\ Wigan, WN1 2NN, UK
}

Received 22 June 2006; accepted 3 October 2006

\begin{abstract}
We describe a patient who was admitted with uncontrolled thyrotoxicosis and carbimazole induced neutropenia. She required $80 \mathrm{mg}$ of carbimazole daily. The patient declined radio-iodine treatment because she had a little child and wished to have thyroid surgery. She received four doses of filgrastim (Granulocyte- colony stimulating factor) which maintained the neutrophil count within a reasonable level while she continued to receive carbimazole to prepare her for surgery. After a curative subtotal thyroidectomy and discontinuation of the carbimazole, the patient's white cell count remained normal. Subsequently the patient was euthyroid on levothyroxine replacement.

Carbimazole should always be discontinued if neutropenia occurs but this case demonstrates that in exceptional circumstances filgrastim can be an effective therapy while continuing carbimazole in the short term.

(c) Versita Warsaw and Springer-Verlag Berlin Heidelberg. All rights reserved.
\end{abstract}

Keywords: Neutropenia, thyrotoxicosis, granulocyte-colony stimulating factor

\section{Case report}

A 24 year old woman was admitted with symptoms of thyrotoxicosis. She was found to have warm sweaty hands, a tachycardia, uncontrolled thyrotoxicosis and low white cell count.

Her past history showed:

*E-mail: indratala@aol.com 
Thyrotoxicosis (Graves' disease) diagnosed five years earlier with carbimazole treatment for two years in the post partum period, followed by a relapse after six months;

Polycystic ovarian syndrome diagnosed at the age of 17 years;

A low normal white cell count and neutrophil count while on carbimazole and iron deficiency anaemia treated with iron tablets in the past

Her medications included carbimazole $60 \mathrm{mg}$ daily and propranolol $10 \mathrm{mg}$ tds. On examination she had a smooth, symmetrical non tender goitre and a heart rate of 116/minute.

Her blood results showed : TSH (thyroid stimulating hormone) not detectable (normal 0.27-4.7 mU/l), FT4 (free thyroxine) $89.4 \mathrm{pmol} / \mathrm{l}$ (normal 12-22 ) and T3 (triiodothyronine) $8.4 \mathrm{nmol} / \mathrm{l}$ (normal 1.3-3.1); Haemoglobin 11.4g/dl (normal 11.5-16.5), MCV (mean corpuscular volume) $70.3 \mathrm{fl}$ (normal 76-100), WCC $2.3 \times 10^{9} / 1$ (normal 4-11) and neutrophil count $0.8 \times 10^{9} / 1$ (normal 1.7-7.5) .

The patient was advised to discontinue carbimazole and have radioactive iodine therapy. However, she declined radioactive iodine therapy because she had a three year daughter at home and the treatment would require her to avoid prolonged close contact with her daughter for 21 days. This was not acceptable to her as she was unable to arrange care for her child and she could not face the separation psychologically. She was fully informed of the possible risks of carbimazole therapy and understood the risks but wished to continue the treatment and to be prepared for thyroid surgery.

The patient was apyrexial. A consultant haematologist with special expertise in filgrastim treatment was asked to give advice about continuing carbimazole therapy and using filgrastim as support in the short term. She was given G-CSF (Granulocyte colony stimulating factor) $300 \mathrm{mcg} /$ day s/c on two consecutive days. The white cell count rose to $9.6 \times 10^{9} / 1$ with a neutrophil count of $7.4 \times 10^{9} / 1$ (see chart). The white cell count continued to vary between 2.8 to $3.6 \times 10^{9} / 1$ and the neutrophil count varied between 1.6 to $2.3 \times 10^{9} / 1$ over the next few days. The carbimazole dose was increased to $80 \mathrm{mg}$ and propranolol was changed to long acting propranolol $80 \mathrm{mg}$ daily. Two weeks later the patient received a third dose of G-CSF as the neutrophil count dropped to $1.1 \times 10^{9} / 1$ (white cell count $\times 10^{9} / 1$ was 2.2 ). Three days later her WCC was $5.7 \times 10^{9} / 1$ and neutrophil $4.5 \times 10^{9} /$ l. Her thyroid status improved on $80 \mathrm{mg}$ of carbimazole daily and the dose was reduced to $60 \mathrm{mg}$ daily. At the time of discharge her thyroid function tests showed TSH not detectable, FT4 $25.4 \mathrm{pmol} / \mathrm{l}$ and T3 $3.0 \mathrm{nmol} / \mathrm{l}$.

The patient was discharged on $60 \mathrm{mg}$ of carbimazole and long acting propranolol $80 \mathrm{mg}$ daily. The patient was referred for an urgent subtotal thyroidectomy. Her haemoglobin was $10.4 \mathrm{~g} / \mathrm{dl}$ with MCV 71fl.

On discharge the patient had a full blood count performed on alternate days with arrangements made for her to receive G-CSF if the neutrophil count dropped to $<1.5 \times$ $10^{9} /$. A week later the patient's thyroid function had improved considerably. Her blood results showed; TSH not detectable, FT4 $18.0 \mathrm{pmol} / \mathrm{l}$ and T3 $3.0 \mathrm{nmol} / \mathrm{l}$.

Two weeks later the patient's white cell count was $2.4 \times 10^{9} / 1$ with a neutrophil count of $1.2 \times 10^{9} / \mathrm{l}$. The patient received another dose of G-CSF. The carbimazole dose was gradually reduced to $40 \mathrm{mg}$ daily with monitoring of the thyroid function. 


\begin{tabular}{|c|c|c|c|c|c|c|}
\hline DAYS & $\begin{array}{c}\text { WCC } \\
\text { (normal: } \\
4-11 \mathrm{x} \\
10^{9} / 1 \text { ) }\end{array}$ & $\begin{array}{l}\text { Neutrophil } \\
\text { (normal: } \\
1.7-7.5 \mathrm{x} \\
\left.10^{9} / \mathrm{l}\right)\end{array}$ & & $\begin{array}{l}\text { Haemoglobin } \\
\text { (normal: } \\
11.5-16.5 \\
\text { g/dl) }\end{array}$ & $\begin{array}{c}\text { FT4 } \\
\text { (normal: } \\
12-22 \\
\mathrm{pmol} / \mathrm{l} \text { ) }\end{array}$ & $\begin{array}{c}\text { T3 } \\
\text { (normal: } \\
1.3-3.1 \\
\text { nmol/l) }\end{array}$ \\
\hline 1 & 2.3 & 0.8 & & 11.4 & 89.4 & 8.4 \\
\hline 2 & 2.4 & 0.9 & & 11.6 & & \\
\hline 3 and 4 & & & $\begin{array}{c}\text { Patient } \\
\text { received two } \\
\text { doses of G-CSF }\end{array}$ & & & \\
\hline 5 & 9.6 & 7.4 & & 12.3 & 60.1 & 6.6 \\
\hline 9 & 3.6 & 2.2 & & 11.2 & 35.9 & 4.1 \\
\hline 14 & 2.2 & 1.1 & $\begin{array}{c}\text { Patient } \\
\text { received one } \\
\text { dose of G-CSF }\end{array}$ & 10.3 & 27.2 & 3.0 \\
\hline $\begin{array}{l}17 \text { (patient } \\
\text { was } \\
\text { discharged) }\end{array}$ & 5.7 & 4.5 & & 10.4 & 25.4 & 3.0 \\
\hline $\begin{array}{l}\text { Two weeks } \\
\text { following } \\
\text { discharge }\end{array}$ & 2.4 & 1.2 & $\begin{array}{l}\text { Patient received } \\
\text { further one } \\
\text { dose of G-CSF }\end{array}$ & 10.8 & & \\
\hline
\end{tabular}

Table 1 White cell count and thyroid profile on different days following admission.

Once euthyroid, the patient underwent a subtotal thyroidectomy. The carbimazole was discontinued and replacement therapy with levothyroxine was started. Six weeks after surgery her white cell count was $4.3 \times 10^{9} / 1$ and neutrophil $2.7 \times 10^{9} / 1$. Her haemoglobin level was $12.9 \mathrm{~g} / \mathrm{dl}$ with MCV of $78.4 \mathrm{fl}$. Thyroid function test results showed TSH 12.28 $\mathrm{mU} / \mathrm{l}, \mathrm{FT} 418.2 \mathrm{pmol} / \mathrm{l}$ and T3 $1.8 \mathrm{nmol} / \mathrm{l}$. She was on levothyroxine $150 \mathrm{mcg} /$ day and iron tablets. The dosage of levothyroxine was increased to $175 \mathrm{mcg} /$ day. Her white cell count and neutrophil count have remained normal ever since.

One year later the patient had a miscarriage. She was treated with metformin 500 mg tds for polycystic ovarian syndrome. Subsequently the patient became pregnant and gave birth to a healthy baby. She is currently taking levothyroxine 225 mcg daily (body mass index $34 \mathrm{~kg} / \mathrm{m}^{2}$ ) and her latest thyroid function tests were normal. The white cell count was also normal.

\section{Discussion}

Carbimazole is known to cause agranulocytosis or aplastic anaemia [1] in 1 to 3 out of 1000 patients which usually occurs within the first 3 months of treatment [2] but can occur later on as well [3].

We report the first patient who received carbimazole and G-CSF simultaneously. The 
CSM (Committee on Safety of Medicines, UK) warns that carbimazole should be stopped promptly if there is clinical or laboratory evidence of neutropenia. The patient was advised to do this and receive radioactive iodine but she did not agree and wished to have thyroid surgery. However surgery could not be undertaken while she was thyrotoxic and so the possibility of continuing the carbimazole while treating her with filgrastim was considered. Thus simultaneously with carbimazole we administered G-CSF (Filgrastim) to maintain the neutrophil count $>1.5 \times 10^{9} /$. From a search of the literature this appears to be the first report of a patient who had G-CSF while on carbimazole. There have been a few reports where carbimazole was withdrawn because of agranulocytosis or aplastic anaemia followed by GCSF therapy [4, 5].

Filgrastim is a human Granulocyte colony stimulating factor (G-CSF), produced by recombinant DNA technology. Colony stimulating factors are glycoproteins which act on haematopoietic cells $[6,7]$ by binding to specific cell surface receptors and stimulating proliferation, differential commitment and some end-cell functional activation. Filgrastim regulates the production and function of neutrophils. Filgrastim controls proliferation of committed progenitor cells and influences their maturation into mature neutrophils. Filgrastim also stimulates the release of neutrophils from bone marrow storage pools and reduces their maturation time. Filgrastim acts to increase the phagocytic activity of mature neutrophils. In patients receiving cytotoxic chemotherapy, filgrastim can accelerate neutrophil recovery, leading to a reduction in duration of the neutropenic phase.

We believe that therapy with G-CSF while continuing with carbimazole should only be given in exceptional circumstances and under very close expert supervision. Apart from exceptional circumstances we would like to emphasise that carbimazole should always be discontinued if neutropenia occurs and then radioiodine is usually the treatment of choice. If agranulocytosis occurs, if the patient is unwell or has signs of infection, then carbimazole should be discontinued without exception.

\section{References}

[1] N. Biswas, A. You-hern , J.M. Goldman and J.M. Schwartz: "Case report: aplastic anemia associated with antithyroid drugs", Am. J. Med. Sci., Vol. 301, (1991), pp. 190-194

[2] G. Birchell and T. Cheetham: "Juvenile thyrotoxicosis; can we do better?", Arch. Dis. Child., Vol. 89(8), (2004), pp. 745-750

[3] U. Srinivas, S. Stanaway, R. Worth and D. Ewins: "Delayed carbimazole induced agranulocytosis precipitating thyroid crisis", Endocrine abstracts, Vol. 5, (2003), P27.

[4] F. Joseph, N. Younis and D. Bowen Jones: "Treatment of carbimazole-induced agranulocytosis and sepsis with granulocyte colony stimulating factor", Int. J. Clin. Prac., Vol. 57(2), (2003), pp .145-146

[5] G. Wilcox, R. Wong, P.J. Elliott, D.J. Topliss and J.R. Sockigt: "Recovery from Carbimazole-Induced Aplastic Anaemia", Int. J. Endocrinol. Metab., Vol. 1, (2003), pp. $41-43$ 
[6] D. Usha , D.M. Thatte and S.A. Dahanukar: "Therapeutic potential of the haematopoietic growth factors", J. Postgrad. Med., Vol. 40(4), (1994), pp. 210-15

[7] A. Oyama, K. Ota, S. Asano, F. Takaku, T. Miyazaki, Y. Uzuka, M. Omine, S. Furusawa, K. Hirashima, K. Sanpi et al: "Clinical effect of recombinant human G-CSF on neutropenia induced by chemotherapy for Non Hodgkin's lymphoma", Nippon Gan. Chiryo. Gakkai. Shi., Vol. 25(8), (1990), pp. 1619-1634. 